Thaddeus L. Bolton, a graduate student in psychology at Massachusetts's Clark University who received a Ph.D. in 1895, appears to have written the first doctoral thesi on a topic closely related to music education. The thesis, tilled "Rhythm," predated by few weeks a music education dissertation written by John I. Dawson a graduate student of education at New York University. Bolton's dissertation describes an experimental study of the reactions of thirty subjects to sounds occurring at different speeds and intensities and with different durations and patterns of accentuation. Bolton's work on rhythm, which appears to have been among the earliest on music by an experimental psychologist, influenced Iowa music supervisor Philip C. Hayden who applied some Bolton's findings to his teaching. Havden's desire to share his applications with others led in large part, to the first meeting (1907) of what became the Music Supervisors National Conference.

Jere T. Humphreys, Arizona State University, Tempe

\section{Thaddeus Bolton and the First Dissertation in Music Education}

Thaddeus L. Bolton (1865-1948) received a Doctor of Philosophy degree (Ph.D.) in psychology in 1895 from Clark University in Worcester, Massachusetts. The research leading to his degree was related to the founding of the Music Supervisors National Conference, now called the Music Educators National Conference, and his doctoral dissertation (or thesis, as it was called) may have been the first dissertation written by an American graduate student on a topic closely related to music education. 1

Bolton was born in Sonora, Illinois, in 1865, and received a bachelor or arts (A.B.) degree from the University of Michigan in 1889 . He served as a school principal in Vulcan, Michigan, in 1889-90, and was

The author acknowledges the following people for assisting with the preparation of this article: Angela Chin, assistant archivist at the Elmer Holmes Bobst Library, New York University; and Stuart W. Campbell, archivist, and Mary Jane Griffin and Eliz, New Yor assistant archivists at the Robert Hutchings Goddard Library Clark Universicy For copies of this article, contact Jere ' $T$. Humphreys, School of Music, Arizona State Univerity, Tempe, AZ 85287 associated with Clark University for several years thereafter: as a "Scholar in Psychology" in 1890-91; an "Assistant and Fellow" in psychology in 1891-92; and as a "Demonstrational Fellow" in psychology in 1892-93. He then served as a "Teacher in Psychology" at the state normal school in Worcester from 1893 to $1896 .^{2}$

\section{Bolton's Thesis}

By the time Bolton received his doctorate, he had published at least three early articles and translations, two of which relate to music. The second of his predoctoral articles on music, bearing the simple title "Rhythm," was published in The American Journal of Psychology in January $1894 .{ }^{3}$ Apparently, reprints of this article were circulated widely, as copies can still be found in research libraries. An examination of the journal article, the reprinted version, and the thesis itself reveals that the three versions are identical in every way except the title pages and page numbers.

The title page of the article contains the following information: "Rhythm by Thaddeus L. Bolton, Demonstrator and Fellow in Psychology, Clark University, Worcester, Massachusetts, Press of F. S. Blanchard and Company, Worcester." The title page of the reprinted version is identical except for the following addition: "(Reprinted from the American Journal of Psychology, Vol. VI. No. 2)."

All of the above information on the title pages, like the remainder of the article, the reprint, and the thesis itself, was typeset. The title page of the thesis is identical to the reprinted title page except for the following additional typewritten statement, which appears to have been added to the reprinted version: "Approved as a thesis for the degree Doctor of Philosophy at Clark University, Worcester, Mass.-G. Stanley Hall."

There is no date on the title page of the thesis, but all three versions include the following information at the end of the complete work: "Clark University, Worcester, Mass., August 1893."

Since the thesis was accepted by the university in January 1894,4 coinciding with the publication of the article, it appears that the journal article was accepted as a thesis, not an uncommon practice of the period.

The person whose name appears on the title page of Bolton's thesis G. Stanley Hall, was the president of Clark University. Hall (1844-1924) was a prominent psychologist, who, in addition to being the university's first president (beginning in 1889), had earned the first Ph.D. in psychology in the United States (1878), founded one of the first psychological laboratories in the United States (1883), founded the American Psychological Association (1892), and founded and edited several journals related to psychology and education, one of which was The American Journal of Psychology (1887).

It is not surprising that the president of the university supervised the writing of Bolton's thesis since the university was at that time a graduatelevel scientific institute dominated by its psychology department. In fact, of fifty-four doctorates in psychology granted by American universities by 1898 , thirty were students of Hall. Furthermore, throughout his long career, Hall was interested in music learning and music psychology. ${ }^{5}$ 
That he worked closely with Bolton is evident from a note on the final page of Bolton's thesis:

To President G. Stanley Hall I am indebted not only for the subject itself, but for a large amount of material which he had already collected upon it; also for suggestions as regards the direction of the experiment and references to literature. ${ }^{6}$

Since Hall edited The American Journal of Psychology, it is likely that he encouraged Bolton to submit the article to his journal, and then accepted it as a thesis

The main portion of the ninety-four-page thesis (and article) describes an experimental study in which Bolton noted the reactions of thirty college-age subjects to "clicks" occurring at different speeds and intensities, and with different durations and patterns of accentuation. The remainder of the thesis describes in considerable detail the laboratory equipment used in the experiment, including a chronograph that furnished steady power to an electric telephone that provided the clicks. ${ }^{7}$ The thesis reveals Bolton's interest in technology and ingenious gadgets, which was common among many experimental psychologists of the period. In fact, Bolton's mentor, Hall, had studied for one year in Leipzig, Germany, under Wilhelm Wundt, who, as one of the world's first and most influential experimental psychologists, was fascinated by creative technology in his experiments.

Bolton asks the following question in his thesis: "Is there not some universal principle which is adequate as an explanation of rhythm in general?"' He later answers his own question:

The general principle is this: In a series of auditory impressions, any regularly recurrent impression which is different from the rest, subordinates the other impressions to it in such a way that they fall together in groups. If the recurrent difference is one of intensity, the strongest impression comes first in the group and the weaker ones after. If the recurrent difference is one of duration, the longest impression comes last.... When the impressions are uniform in length and intensity, the mind enforces a grouping by giving fictitious values to the impressions, generally with respect to intensity, but sometimes with respect to duration. ${ }^{9}$

Bolton's findings were cited frequently by other psychologists during the next few years. Most seem to have accepted his conclusions, although some found them unconvincing. Decades later, he was credited with having been the first person to treat "the subject of music as a science," 10 despite the fact that Wundt and other German psychologists had conducted earlier experiments similar to Bolton's and that Bolton himself was aware of those experiments. ${ }^{11}$ Neither did he claim to be the first to research aesthetic aspects of music, only to have "attempt[ed] to push the lines of exact science a little farther forward into a field that borders more closely upon the field of aesthetics than any other that experimental psychologists have tried. ${ }^{12}$ Bolton appears to have been, however, among the first group of experimental psychologists to study musical perception for its own sake, rather than simply as a means for measuring sense perception, music's effects on reaction times, or music as a distraction from other tasks, all popular areas of investigation among experimental psychologists of the period.

\section{The First Dissertation Related to Music Education}

Bolton's Ph.D. was awarded on April 30, 1895,13 just weeks before John J. Dawson was awarded a Doctor of Pedagogy degree (Ped.D.) by New York University's School of Pedagogy, the first university school of education in the United States with full academic status. Roger P. Phelps has argued that Dawson was the recipient of the first earned doctorate in music education. ${ }^{14}$

According to the New York University School of Pedagogy's "Faculty Minutes," Dawson's dissertation was submitted on May 4, 1895, and "unanimously approved" on May 22. On May 25, the School of Pedagogy faculty "moved and carried" that Dawson be recommended for a Doctor of Pedagogy degree. ${ }^{15}$ The New York University commencement program that listed Dawson's name-along with five others who received the same degree-was dated June 6,1895 , presumably the date Dawson actually received his degree. ${ }^{16}$ Unlike New York University, which held annual commencement ceremonies, Clark University had no formal commencement at that time, and simply awarded degrees upon completion of the requirements; in this case, April 30, 1895 (see Table 1). ${ }^{17}$

Even though Bolton finished before Dawson, several facts support Phelps's claim that Dawson received the first earned doctorate in music education. First, Dawson's dissertation, entitled "The Education Value of Vocal Music," a sixteen-page (single-spaced) discussion of vocal music and music education in the schools and in society, clearly relates to music education. 18 Second, Dawson's degree was a Doctor of Pedagogy

Table 1

Chronology of Events Leading to Bolton's and Dawson's Doctorates

\begin{tabular}{lll}
\hline Date & Bolton & Dawson \\
\hline August 1893 & $\begin{array}{l}\text { Article signed } \\
\text { January } 1894\end{array}$ & $\begin{array}{l}\text { Article published and } \\
\text { thesis accepted }\end{array}$ \\
April 30,1895 & Ph.D. granted & Dissertation signed \\
May 4, 1895 & Dissertation submitted \\
May 22, 1895 & Dissertation approved \\
May 25, 1895 & Ped.D. approved \\
June 6, 1895 & Ped.D. granted
\end{tabular}


(Ped.D.), precursor of the Doctor of Education degree (Ed.D.) in common use in music education today. In fact, New York University's School of Pedagogy was renamed the School of Education in 1922, after which the degree title was changed from Ped.D. to Ed.D. ${ }^{19}$ Finally, research has failed to find evidence of the granting of an earlier degree that relates closely to music education.

Because Thaddeus Bolton's degree was in psychology, he cannot be given credit for having completed the first doctorate in music education. He can be credited, however, with having written the first dissertation (thesis) on a music education topic. Therefore, in the absence of evidence of earlier dissertations and doctoral degrees, Dawson should be credited with having earned the first doctorate in music education, and Bolton should receive credit for having written the first dissertation related to music education. In any event, Boiton's thesis appears to have been the first of the many early theses and dissertations on music written by graduate students of psychology, ${ }^{20}$ and both Bolton's work in psychology and Dawson's in education predated by several years doctoral dissertations relating to music education written under the auspices of departments and schools of music in the United States.

\section{The Founding of the Music Supervisors National Conference}

Bolton's influence on music education came through the well-known music educator Philip C. Hayden, a music supervisor in Keokuk, Iowa, who was also the editor and founder of School Music. Later, this publication merged with School Music Monthly and was subsequently known by the latter title; the new joint publication was the first longstanding magazine devoted to music education.

Hayden attempted to apply some of Bolton's findings to his own teaching, and he presented a demonstration on the subject at the 1905 meeting of the National Educational Association. ${ }^{21}$ Hayden then sent letters to a group of music supervisors, inviting them to visit Keokuk in 1907 to:

have a convention of the [music] supervisors of the middle west to last, say two days, comprising six lessons with a regular program, my work on ear training in rhythm forms to take up two or three of these sessions, the rest of the meeting to be given up to problems of general interest, to papers and discussions. ${ }^{22}$ [emphasis added]

Hayden's letter to the approximately thirty music supervisors also contained the following description of his method of teaching rhythm:

During the last year $I$ have completed a method of practicing these "rhythm forms." The application of foundation principles which I make in classifying the elements of music is so original, the meihod used in training the ear to recognize the different rhythm groupings so new, and the results of this new method are so entirely satisfactory that $I$ am extremely anxious to have the work inspected by a large group of supervisors. ${ }^{23}$

Hayden did not acknowledge Bolton's influence on his system for teaching rhythm in that letter, but he had done so on other occasions, as, for example, when he wrote that Bolton's experiments "scientifically proved" the tendency of the human ear to hear sounds in groups of twos, threes, and fours. ${ }^{24}$

We cannot be certain how Hayden received his information about Bolton's work due to the former's failure to provide bibliographic citations. The most likely source was Hayden's association with G. Stanley Hall at one or more meetings of the National Educational Association (NEA). Hayden claimed to have attended ten of twelve national meetings of the NEA from 1892 through $1903,{ }^{25}$ and, in fact, both Hayden's and Hall's names appear in the program (or minutes) for four meetings during those years: 1892, 1896, 1901, and 1903. Furthermore, Hayden is listed as one of a "large number" who exhibited "great interest" in Hall's address to the NEA's Department of Music Education in 1896 , and he may have heard Hall's deprecatory remarks about the status of music teaching at a general session of that same national meeting. ${ }^{26}$ There is no direct evidence for Hayden's association with Hall at the other three NEA meetings mentioned above, but the 1903 meeting could have been the occasion, since it occurred just before Hayden said that he implemented his new teaching syster. ${ }^{27}$

Further evidence for Hall as Hayden's contact rather than Bolton is that: (1) Bolton wrote sparingly on music, and seems to have written nothing, other than his thesis, that has any similarity to Hayden's references; (2) Hayden is unlikely to have had access to a copy of Bolton's thesis or The American Journal of Psychology; (3) Hayden made references to things that Bolton never wrote about, including "hundreds of experiments [at Clark University] to determine the nature of rhythm," 28 and the recapitulation theory, a pet theory of Hall's but apparently not of Bolton's. ${ }^{29}$ The popular Clark University Summer Schools were another possible point of contact between Hayden and Bolton or Hall, although the surviving class rosters do not include Hayden's name. ${ }^{30}$

Regardless of how Hayden received his information, the meeting in Keokuk in 1907 was the first of what became the Music Supervisors National Conference. The 104 persons in attendance did witness Hayden's teaching of rhythm to school students based upon Bolton's principles, although according to Edward Bailey Birge, who was one of the attendees, the results of the demonstration were "not conclusive." 31 Regardless of the results, Hayden's demonstration of the teaching of rhythm forms was the first of what became a regular feature of future conferences: demonstrational clinics. ${ }^{32}$

Hayden demonstrated his methods at a number of other professional meetings after the Keokuk meeting, ${ }^{33}$ including the second meeting of the new organization in Indianapolis, Indiana, in 1909, when he said that "groups of beats or pulses" are analogous to tones in the chromatic scale "taken in their varying relations." He added that "this conception of rhythm ... has been confirmed by studying the results obtained by investigators at Clark University," where "experiments showed that when a group of tones, of absolute equality of movement and power, 
were listened to for several minutes, the mind began to place them in groups." 34 . After stating that this phenomenon is "nature's way," he once again gave credit to Clark University and to Thaddeus Bolton. ${ }^{35}$

One writer, Chester Channon, has suggested that Hayden's advocacy of combining tonal and rhythmic problems from the beginning both in ear training and in eye training "was a step in advance of his predecessors. True, his plan of presentation through rhythm forms has been discarded, but the basic idea of combining in one operation in music reading tonal and rhythmic facts has been generally adopted." 36 Channon also states that ideas developed as a result of discussions following Hayden's demonstrations were used later in song series and in the accompanying teachers' manuals. ${ }^{37}$

Music educators before Hayden had been influenced by the scientific craze then sweeping the nation, ${ }^{38}$ but he may have been the first practicing music educator whose teaching was affected by controlled research on musical learning and perception. If Bolton was indeed one of the first psychologists to study musical perception in both a scientifi. cally controlled and musically defensible way, Hayden was among the first generation of music educators who had an opportunity to apply such findings.

\section{Conclusions}

After completing his doctorate, Bolton taught at the state normal school in San Jose, California, in 1896-97, the University of Washington, Seattle, in 1897-98, and completed postgraduate studies at the University of Heidelberg (Germany) in 1898-99. He taught at the University of Nebraska from 1899 to 1910, Tempe (Arizona) Normal School from 1910 to 1913, the University of Montana from 1913 to 1917 , and Temple University from 1917 to $1937 .{ }^{39}$ He became interested in a wide variety of subjects other than music, and soon relinquished his brief tenure as the leading music psychologist. ${ }^{40}$ That distinction then fell to Carl E. Seashore of the University of Iowa, who later shared it with James L. Mursell of Columbia University.

Bolton achieved enough prominence in his field to be among the first fifty psychologists awarded a "star" in the American Men of Science, 41 and apparently he was fairly well known and respected until his death in 1948.42 Perhaps because he was an eclectic who worked in a number of fields rather than specializing in one, Bolton's name is not found in most contemporary standard biographical reference works for the field of psychology

It is significant that Bolton's relatively high-quality research on musical perception resulted in one of the first, if not the first, doctoral dissertations related to music education, that the study on which the thesis was based may have been the first controlled research study to influence the teaching of a leading music educator, and that the research played such an important role in the first meeting that led to the founding of the music education profession's largest and most influential organization-the Music Educators National Conference.

\section{NOTES}

1. Thaddeus L. Bolton, "Rhythm" (Ph.D. thesis, Clark University, Worcester, Massachusetts, 1895). Clark University Archives.

2. Student records, Clark University Archives, Worcester, Massachusetts.

3. Thaddeus L. Bolton, "Rhythm," The American Journal of Psychology 6 (January 1894): 145-238. Bolton's earlier article relating to music was "On the Discrimination of Groups of Rapid Clicks," The American Journal of Psychology 5 (April 1893): 294-310.

4. Student records, Clark University Archives.

4. Student records, Clark University Archives.
5. Edwin G. Boring, A History of Experimental Psychology, 2d ed. (New York: Appleton5. Edwin G. Boring, A History of Experimental Psychology, $2 \mathrm{~d}$ ed. (New York: Appleton-
Century-Crofis, 1950), 545; and Dorothy Ross, G. Stanley Hall: The Psychologist as Prophet Century-Crofis, 1950), 545; and Dorothy Ross, G. Stanley Hall: The Psychologist as Prophet
(Chicago: University of Chicago Press, 1972), 231, 237. For more information on Hall's (Chicago: University of Chicago Press, 1972), 231, 237. For more information on Halls influence on music education see Roger Ralph Rideout, "Granville Stanley Hall and Music Education: 1880-1924" (Ed.D. diss., University of Illinois, 1978) and his article "On Early
Applications of Psychology in Music Education," Journal of Research in Music Education, 30 (Fall 1982): 141-50

6. Bolton, "Rhythm" (Ph.D. thesis), 94. After Hall's death in 1924, Bolton wrote, "Indced I am saddened by the announcement of Dr. Hall's death ... [he] had the capacity to approach young men of ability and set them to work ... my education began when I met him. He was what I sought for ... I am grateful to him as to nobody else" (personal letter from Thaddeus L. Bolton to Edmund C. Sanford, Professor of Experimental Psychology, Clark University, April 26, 1924, Clark University Archives, Worcester, Massachusetts.

7. Bolton, "Rhythm" (Ph.D. thesis), 34-94.

7. Bolton,

8. Ibid., 2.
9. Ibid., $88-89$

10. The National Cyclopaedia of American Biography, vol. 36 (New York: James T. White \& Co., 1950$), 104$

11. Bolton, "Rhythm" (Ph.D. thesis), 61-62; in one earlier experiment upon which Bolton may have based his work, investigators noted, incidentally, that subjects "grouped" beats generated by a metronome; James R. Angell and Arthur H. Pierce, "Experimental Research Upon the Phenomena of Attention," The American Journal of Psychology 4 (April 1892): $528-41$. 12. Bolton, "Rhythm" (Ph.D. thesis), 2. Two examples of earlier studies of musical
expressiveness are Benjamin Ives Gilman's "Report on an Experimental Test of Musical expressiveness are Benjamin lves Gilman's "Report on an Experimental Test of Musical Expressiveness," The American Journal of Psychology 4 (August 1892): $558-76$ and his "Report of [on] an Experimental T

13. Student records, Clark University Archives.

14. New York University was then called the University of the City of New York. See Roger P. Phelps, "The First Earned Doctorate in Music Education," The Bulletin of Historical Research in Music Education, 4 (January 1983): 1-6.

15. "Faculty Minutes," School of Pedagogy, New York University, May 4, May 22, and May 25, 1895.

16. "Commencement Program," New York University, June 6, 1895; May 31, 1894. Dawson received his doctorate just one year after completing a Master of Pedagogy degree at the same institution.

17. Angela Chin, assistant archivist, Elmer Holmes Bobst Library, New York University, telephone conversation with author June 3, 1987; and Mary Jane Griffin, assistant telephone conversation with author, June 3 , 1987; and Mary Jane Griffin, assistant archivist, Robert Hutchings Goddard Library, Clark University, telephone conversation
with author, May 28, 1987. Coincidentally, April 30, 1895, was the date given by Dawson, along with his city of residence and signature, on the final numbered page of his dissertation; John J. Dawson, "The Education Value of Vocal Music" (Ped.D. diss., New York University, 1895), 16.

18. Dawson, $1-16$

19. Chin, June 3,1987

20. One of the earliest dissertations was Charles William Johnson, "Musical Pitch and Measurement of Intervals Among the Anciut Greeks" (Ph.D. diss, Johns Hopkins Measuric tions by several students who worked under the direction of Carl $E$. Seashore at the 

University of lowa in the early twentieth century to develop the first standardized tests of
musical aptitude.

21. "Secretary's Minutes: Department of Music Education," Joumai of Proceedings and Addresses of the National Educational Association (Winona, Minnesota: National Educational
Association, 1905), 628 .

22. Philip C. Hayden, "Letter to Music Supervisors," November 27, 1906; reprinted in School Music Monthly 8 (January 1907): 6.

23. Ibid.

24. Philip C. Hayden, "The Place of Rhythm in Classifying and Teaching the Elements of Music," School Music Monthly 7 (January 1906): 23. For a more complete descriptionts Hayden's rhythm forms and his writings about them see Chester $N$ Channon "Th Contributions of Philip Cady Hayden to Music Education in the United States" "The diss., University of Michigan, 1958), 46-61.

25. Philip C. Hayden, "N.E.A.," School Music Monthly 4 (May 1903): 17, 20; cited by Channon, "The Contributions of Philip Cady Hayden," 120

26. "Secretary's Minutes: Department of Music Education," Journal of Proceedings and Addresses of the National Educational Association (Chicago: National Educational Association, 1896), 717-18; G. Stanley Hall, "Some of the Methods and Results of Child Study Work at Clark University [abstract]," Journal of Proceedings and Addresses of the Naitonal Educational Association (Chicago: National Educational Association, 1896), 860-64. When Hayden later referred to the 1896 NEA meeting, he even mentioned Hall by name; P[hilip] C. Hayden, "The Ultimatc Object of Music Study in the Schools," Journal of Proceedings and Addresses of the National Educational Association (Chicago: National Educational Association, 1899), 972-

27. Hayden, "Letter to Music Supervisors," 6. In his original letter of invitation to music supervisors in November 1906, Hayden said, "This is the fourth year I have been basing all my work in school music on rhythm," which suggests that he began in the fall of 1903 ,

28. Philip C. Hayden, "Rhythm and Beating Time," School Music Monthly 10 (May-June

29. Hayden referred to recapitulation theory, although not by name, in Philip C. Hayden, [Untitled], School Music Monthly 6 (November 1905): 28-30.

30. "Summer School Registers," 1894, 1896, 1897, 1898, 1899, 1903. Clark University Archives.

31. Edward Bailcy Birge, History of Public School Music in the United States. Reprint. (Music Educators National Conference, 1966), 246-47. Birge may have been overly diplomatic his description of the results of Hayden's demonstration; for a rather iengthy description and explanation of Hayden's 1907 demonstration see Philip C. Hayden "Therion Supervisors' Conference at Keokuk, lowa, April 10 to 12, 1907," School Music Mont (May 1907): 15-17, 20-26, 38-42 Lenol Must Monthly 8

32. Channon, "The Influence of Philip Cady Hayden," 78

33. Ibid., 76-77.

34. Hayden, "Rhythm and Beating Time," 31-32.

35. Ibid.

36. Channon, "The Influence of Philip Cady Hayden," 147

37. Ibid., 78

38. Jere T. Humphreys, "Applications of Science: The Age of Standardization and Efficiency in Music Education," The Bulletin of Historical Research in Music Education 9 (January 1988): 1-21.

39. Who Was Who in America, vol. 2 (Chicago: A. N. Marquis Co., 1950), 69.

40. The National Cyclopaedia, 104. Bolton did continue some involvement with music research as evidenced by his direction of at least two master's theses related to music: $F$ Edna Davis, "An Attempt to Correlate Musical Ability with Athletic Ability," Master's thesis, Temple University, Philadelphia, 1927; and Alex Washco, Jr., "Selection and Guidance of the Musically Gifted," Master's thesis, Temple University, 1928.

41. Later renamed American Men and Women of Science.

42. The National Cyclopaedia, 104. He was also remembered by his mentor, G. Stanley Hall, who listed his name among twenty-five (from a total of eighty-one) doctoral graduates from Clark University with whom he had worked and whom he beiieved had become the best-known psychologists. Hall's objectivity in drawing up that list has been questioned, however, since some persons he included were no longer at the forefront of their profession. See Boring, A History of Experimental Psychology, 546.

\section{REFERENCES}

Angell, James R., and Arthur H. Pierce. "Experimental Research Upon the Phenomena of Attention." The American Journal of Psychology 4 (April 1892): $528-41$.

Birge, Edward Bailey. History of Public School Music in the United States. Reprint Washington, D.C.: Music Educators National Conference, 1966.

Bolton, Thaddeus L. "On the Discrimination of Groups of Rapid Clicks." The American Journal of Psychology 5 (April 1893): 294-310.

- Personal letter to Edmund C. Sanford, April 26, 1924. Clark University Archives.

. "Rhythm." Ph.D. thesis, Clark University, Worcester, Massachusetts, 1895.

. "Rhythm." The American Journal of Psychology 6 (January 1894): 145-238

Boring, Edwin G. A History of Experimental Psychology, 2d ed. New York: Appleton-Century-Crofts, Inc., 1950.

Channon, Chester N. "The Contributions of Philip Cady Hayden to Music Education in the United States." Ed.D. diss., University of Michigan, Ann Arbor, 1958

Chin, Angela. Telephone conversation with author, June 3, 1987.

"Commencement Program." New York University. May 31, 1894; June 6, 1895

Davis, F. Edna. "An Attempt to Correlate Musical Ability with Athletic Ability." Master's thesis, Temple University, Philadelphia, 1927.

Dawson, John, J. "The Education Value of Vocal Music." Ped.D. diss., New York University, 1895.

"Faculty Minutes." School of Pedagogy, New York University. May 4, 1895; May 22, 1895; May 25, 1895

Gilman, Benjamin Ives. "Report of [on] an Experimental Test of Musical Expressiveness." The American Journal of Psychology 5 (October 1892): 42-73.

"Report on an Experimental Test of Musical Expressiveness." The American Journal of Psychology 4 (August 1892): 558-76.

Griffin, Mary Jane. Telephone conversation with author, May 28, 1987.

Hall, G. Stanley. "Some of the Methods and Results of Child Study Work at Clark University [Abstract]." Journal of Proceedings and Addresses of the National Educational Association. Chicago: National Educational Association, 1896: 86064.

Hayden, Philip C. [Untitled]. School Music Monthly 6 (November 1905): 28-30.

- "Letter to Music Supervisors." November 27, 1906. Reprinted in School Music Monthly 8 (January, 1907): 6.

"N.E.A." School Music Monthly 4 (May 1903): 17, 20.

-. "Rhythm and Beating Time." School Music 10 (May-June 1909): 27, 30-

35

'The Music Supervisors' Conference at Keokuk, Iowa, April 10 to 12 1907." School Music Monthly 8 (May 1907): 15-17, 20-26, 38-42.

"The Place of Rhythm in Classifying and Teaching the Elements of Music." School Music Monthly 7 (January 1906): 17, 20-26.

. "The Ultimate Object of Music Study in the Schools." Journal of Proceedings and Addresses of the National Educational Association. Chicago: $\mathrm{Na}$ tional Educational Association, 1899, 972-77. 
Humphreys, Jere T. "Application' of Science: The Age of Standardization and Efficiency in Music Education." The Bulletin of Historical Research in Music Education 9 (January 1988): 1-21.

Johnson, Charles William. "Musical Pitch and the Measurement of Intervals Among the Ancient Greeks." Ph.D. diss., John Hopkins University, Baltimore Maryland, 1896.

The National Cyclopaedia of American Biography, Vol. 36. New York: James T White \& Co., 1950.

Phelps, Roger P. "The First Earned Doctorate in Music Education." The Bulletin of Historical Research in Music Education 4 (January 1983): 1-6.

Rideout, Roger Ralph. "Granville Stanley Hall and Music Education: 1880 1924." Ed.D. diss., University of Illinois, Urbana, IL, 1978.

- "On Early Applications of Psychology in Music Education." Journal of Research in Music Education 30 (Fall 1982): 141-50.

Ross, Dorothy. G. Stanley Hall: The Psychologist as Prophet. Chicago: University of Chicago Press, 1972

"Secretary's Minutes: Department of Music Education." Journal of Proceedings and Addresses of the National Educational Association. Chicago: National Educational Association, 1896, 717-18.

"Secretary's Minutes: Department of Music Education." Journal of Proceedings and Addresses of the National Educational Association. Winona, Minnesota: National Educational Association, 1905: 627-30.

Student Records, 1890-96. Clark University Archives.

"Summer School Registers." 1894, 1896, 1897, 1898, 1899, 1903. Clark University Archives.

Washco, Alex, Jr. "Selection and Guidance of the Musically Gifted." Master's thesis, Temple University, Philadelphia, 1928.

Who Was Who in America. Vol. 2. Chicago: A. N. Marquis Co., 1950.

\section{Announcements}

\author{
Call for Papers \\ "National In-Service Conference \\ on the Value of Music Learning" \\ Winston-Salem, North Carolina \\ November 10-12, 1990
}

Researchers are invited to submit research papers for the "National In-Service Conference on the Value of Music Learning," to be held in Winston-Salem, North Carolina, November 10-12, 1990. The conference, emphasizing the development of music competencies through reading, listening, and performance, is being sponsored by the Southern Division of MENC and the North Carolina Music Educators Association. All individuals, including those who have investigated music reading, listening, and performance in choral, instrumental, and general music learning environments, are encouraged to submit reports by July 1 , 1990. Submissions will be reviewed by a panel of qualified judges; applicants will be notified of the results by August 15, 1990. For further information contact Patricia E. Sink, School of Music, University of North Carolina at Greensboro, Greensboro, NC 27412-5001, or call 919-334-5789.

\section{"Research in General Music" A Symposium Sponsored by the School of Music of The University of Arizona, Tucson February 14-16, 1991}

The University of Arizona (Tucson) School of Music will sponsor a symposium titled "Research in General Music," to be held February 1416,1991 . The symposium's purpose is to provide a setting in which recent research studies whose results have implications for general music instruction can be communicated and discussed with other scholars. Speakers and discussants will include Paul A. Haack; Sally Monsour; Jeffrey Kimpton; Kenneth H. Phillips; David G. Woods; and Andrew Weil, M.D., author of The Natural Mind. Registration information may be obtained by contacting Steven K. Hedden, Symposium Director, School of Music, The University of Arizona, Tucson, AZ $85721 ; 602-621-3231$. Those who plan to attend the symposium should make travel arrangements as soon as possible to obtain special fares for airline tickets. 